\title{
First record of a fish-killing Gymnodinium sp. bloom in Kuwait Bay, Arabian Sea: chronology and potential causes
}

\author{
Cynthia A. Heil ${ }^{1, *}$, Patricia M. Glibert ${ }^{2}$, Mohammad A. Al-Sarawi ${ }^{3}$, Muna Faraj $^{3}$, \\ Manaf Behbehani ${ }^{4}$, Muna Husain ${ }^{5}$
}

\author{
${ }^{1}$ College of Marine Science, University of South Florida, 140 7th Avenue S, St. Petersburg, Florida 33701, USA \\ ${ }^{2}$ University of Maryland Center for Environmental Science, Horn Point Laboratory, PO Box 775, Cambridge, Maryland 21613, USA \\ ${ }^{3}$ Kuwait Environment Public Authority, PO Box 24395, Safat 13104, Kuwait \\ ${ }^{4}$ Department of Biological Sciences, Faculty of Science, Kuwait University, PO Box 5969, Safat 13060, Kuwait \\ ${ }^{5}$ Kuwait Environment Public Authority, Marine Laboratory, PO Box 2221, Al Surrah 45400, Kuwait
}

\begin{abstract}
Significant natural and aquaculture fish deaths in Kuwait Bay occurred from September to October of 1999 and were attributed to a bloom of the dinoflagellate Gymnodinium sp. A chronology of the bloom event suggests that a period of low winds and stable water-column structure preceded the bloom. Maximum cell concentrations of Gymnodinium sp. $\left(>6 \times 10^{6}\right.$ cells $\left.^{-1}\right)$ were also immediately preceded by a more than 20 -fold increase in mean inorganic nitrogen concentrations (up to $60 \mu \mathrm{M}$ ) and elevated inorganic phosphate concentrations. This, combined with elevated inorganic and organic nutrient concentrations within the bloom, suggests that coastal nutrient eutrophication was likely to have contributed significantly to bloom development and support. Termination of the Gymnodinium sp. bloom coincided with a bloom of the non-toxic ciliate Mesodinium rubrum, which appeared as large red patches in Kuwait Bay. While no adverse human health effects were associated with the bloom, closure of shellfish and selected finfish (largely mullet Liza macrolepis) markets resulted in significant economic losses to the region. The occurrence of this toxic algal bloom event, the first within the Arabian Sea, highlights the need for monitoring and research programs in the Arabian Sea and Kuwait Bay that focus on nutrients and eutrophication, in addition to oil related pollution issues.
\end{abstract}

KEY WORDS: Arabian Sea $\cdot$ Kuwait Bay $\cdot$ Gymnodinium sp. $\cdot$ Mesodinium rubrum $\cdot$ Eutrophication · Fish kill $\cdot$ Nitrogen $\cdot$ Nutrients $\cdot$ Red tide

Resale or republication not permitted without written consent of the publisher

\section{INTRODUCTION}

The Arabian Gulf is a shallow, semi-enclosed marginal sea characterized by both extreme natural environmental conditions and severe anthropogenic stresses. Evaporation exceeds combined rainfall and coastal freshwater inputs to this region by a factor of 10 (Sheppard 1993). This, combined with an average flushing time of 3 to 5 yr (Hunter 1986), results in salinities of up to $44.30 \%$ (Saad 1976, Jacob \& Al-Muzaini

*E-mail: cheil@seas.marine.usf.edu
1990). Water temperatures vary from 12 to $>32^{\circ} \mathrm{C}$ (ROPME 1999). Superimposed on these extreme environmental conditions are a series of unique environmental pressures. Oil-related pollution inputs to the Gulf, especially the northern Gulf, are immense. PreGulf War inputs alone are estimated to have been 47 times that of the remaining total estimated global oil pollution (Golob \& Bruss 1984), and estimates of direct Gulf War-related oil inputs range from 6 to 12 million barrels (Readman et al. 1992, Cava et al. 1993, Literathy 1993). In the northern Gulf, major point-source pollutant inputs include sewage outfalls from Kuwait City and outfalls associated with industrial, desalina- 
tion and power plant complexes to the north of Kuwait City. Additionally, a large drainage channel (anecdotally known as the 'third river'), constructed after the 1991 Gulf War by Iraq, drains the southwest Al-Ahwar wetlands of coastal Iraq at the Iraq-Kuwait border. This channel has resulted in a localized reduction in salinity and has shifted the source of nutrient inputs from Shatt Al-Arab directly into Kuwaiti waters. The long-term consequences of this change are unknown (ROPME 1999).

Subba Rao \& Al-Yamani (1998) have summarized available knowledge of phytoplankton from the northern Arabian Gulf and described the region as a distinct biotope, with a north-south gradient in phytoplankton diversity and abundance. Populations within the Tigris and Euphrates River estuaries are characterized by greater biomass, but are less diverse than those of open Gulf waters to the south. Little information is available on phytoplankton rate processes within the region beyond infrequent primary production measurements (Al-Abaychi \& Ghani 1986, Hadi et al. 1989, Sheppard et al. 1992, Subba Rao \& Al-Yamani 1998).

The occurrence of harmful algal blooms is often cited as symptomatic of increasing coastal environmental stresses, including eutrophication, pollution and increases in aquaculture (see review in Hallegraeff 1995). Available phytoplankton species lists from the Arabian Sea (see Subba Rao \& Al-Yamani 1998 for summary) suggest that some potentially harmful species are present within the region. In September of 1999, a major fish kill occurred in Iranian coastal waters and was immediately followed by wild and aquaculture-related fish kills in Kuwaiti coastal waters. Mortality (at least in Kuwait waters) was related to the presence of a red tide outbreak of the dinoflagellate Gymnodinium sp., previously identified only from New Zealand coastal waters (MacKenzie et al. 1995, 1996, Haywood, Steidinger, Truby \& Mackenzie unpubl.). This as yet undescribed species is being named 'selliformis' after its saddle-shaped hypothecal notch (Haywood et al. unpubl.) We report here a chronology of the bloom, environmental conditions during the bloom, potential causes, and the implications for environmental monitoring in the Arabian Gulf.

\section{METHODS}

Kuwait Bay is a large $\left(\sim 850 \mathrm{~km}^{2}\right)$, sub-tropical, semienclosed embayment located in the northwest region of the Arabian Sea (Fig. 1). The Bay is shallow, with a maximum depth of $20 \mathrm{~m}$ and a mean depth of $<3 \mathrm{~m}$ (Anderlini et al. 1982), so most of it lies within the photic zone year-round (Sheppard 1993, Carpenter et al. 1997). The tidal range is $>1 \mathrm{~m}$, and mixing and

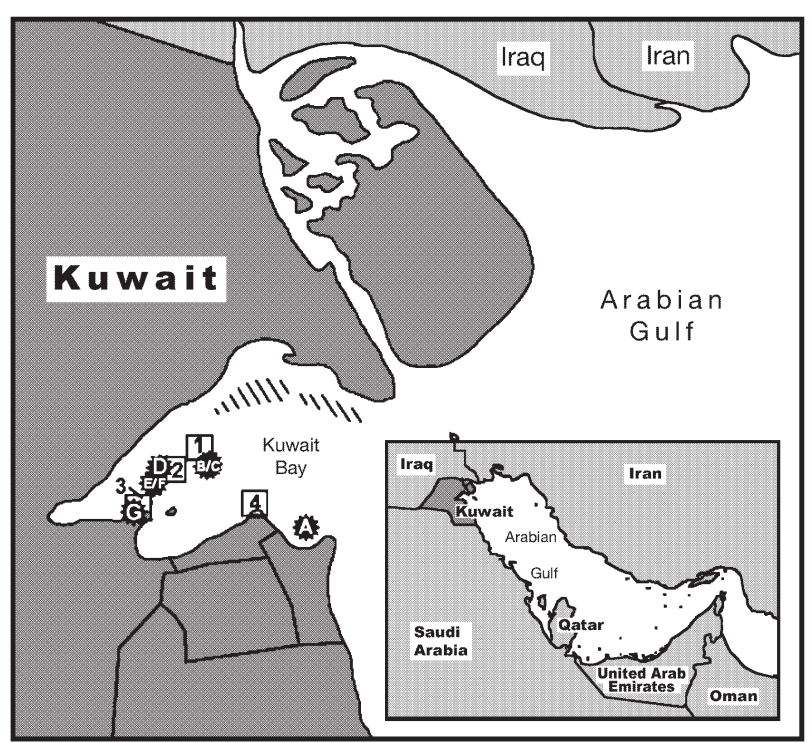

Fig. 1. Map of Kuwait Bay. Stns 1 to 4 were sampled on October 14, 1999 and represent the Kuwait Environment Public Authority (EPA) long-term monitoring stations. Stns A to G were sampled on October 15, 1999. Hatched area is the region which experienced fish kill of mullet on September 19, 1999

circulation are largely wind-driven (Lehr 1984, AbouSeida \& Al-Sarawi 1990, Reynolds 1993).

Samples for phytoplankton community composition and nutrient analyses were collected during the Kuwait red tide outbreak on October 14 and 15, 1999, at a range of sites located throughout Kuwait Bay (Fig. 1). Four stations sampled from 10:00 to 12:00 h on October 14 coincided with long-term monitoring stations maintained by the Kuwait Environment Public Authority (EPA). Seven additional stations, selected to cover a range of environmental conditions including fish-kill areas, aquaculture cages and areas adjacent to major industrial outfalls, were sampled on October 15 from 09:00 to 12:00 h.

Water samples were collected with a modified Niskin bottle from $10 \mathrm{~cm}$ below the water surface, stored in a shady area on the boat, and returned to the laboratory within $3 \mathrm{~h}$ of collection. Nutrient samples were immediately filtered onto precombusted GF/F filters $\left(450^{\circ} \mathrm{C}\right.$ for $1 \mathrm{~h}$ ), frozen, and later transported on ice to Horn Point Laboratory, University of Maryland, Cambridge, USA, for analysis. The filters were retained for chlorophyll $a$ analysis (Parsons et al. 1984). All samples remained frozen during transport. Inorganic nutrients $\left[\mathrm{NO}_{3}{ }^{-}\right.$, $\mathrm{NH}_{4}{ }^{+}, \mathrm{PO}_{4}{ }^{3-}$ and $\mathrm{Si}(\mathrm{OH})_{4}$ ] were analyzed using standard autoanalyzer methods (Parsons et al. 1984). Samples for total dissolved nitrogen were analyzed on Antek Instruments high-temperature oxidation instruments, calibrated using a urea standard (Bronk et al. 2000). Concentrations of dissolved organic nitrogen 
(DON) were calculated by subtracting all inorganic nitrogen concentrations from the total dissolved nitrogen concentrations. Samples for total dissolved phosphate were oxidized using the persulfate oxidation method (Valderrama 1981) and analyzed on an autoanalyzer as described above. Dissolved organic phosphorus (DOP) concentrations were calculated as the difference between total dissolved phosphate and $\mathrm{PO}_{4}{ }^{3-}$. Samples for dissolved organic carbon (DOC) were analyzed on a Shimadzu TOC instrument. Additional unpublished inorganic nutrient data from the months immediately prior to the bloom were made available by the Kuwait monitoring program.

Gymnodinium sp. and Mesodinium rubrum concentrations were determined prior to sample preservation within $1 \mathrm{~h}$ of return to the laboratory. Samples were mixed by gently inverting the sample container twice, then duplicate $0.1 \mathrm{ml}$ volumes from each sample were counted using a Palmer-Maloney counting chamber and an Olympus BH-2 microscope according to Throndsen (1995). Approximately $100 \mathrm{ml}$ of water from each station was preserved with Lugol's solution for subsequent analysis of phytoplankton composition with an inverted microscope according to Hasle (1978). Community composition was determined to species level when possible, and size measurements were made using an Olympus ocular micrometer.

\section{RESULTS}

A chronology of the bloom event is given in Table 1. A fish kill in Iranian waters preceded by more than 1 mo the first reported fish kill (primarily mullet, Liza macrolepis), which was observed in Kuwaiti waters on September 19. The direct cause of the fish kill off Iran was not documented. Discolored water was observed in both northern and southern Kuwait Bay throughout the week following this initial large fish kill, and a large fish kill (sobaity, Acanthopagrus cuvieri, 80000 fish) in aquaculture enclosures in northern Kuwait Bay occurred on October 1 and 2. A bloom of a gymnodinioid dinoflagellate (Fig. 2) was identified as the cause of the fish kills by Kuwaiti EPA personnel on October 2 based upon high (>6 $\times 10^{6}$ cells $\mathrm{l}^{-1}$ ) Gymnodinium sp. cell concentrations in areas with fish kills and the elimination of other potential causes (e.g. accidental discharge of chemical pollutants, oil and trace metals) via intensive measurements made subsequent to the first fish kill (Kuwait EPA 1999). Following the peak of the Gymnodinium sp. bloom, red water caused by Mesodinium rubrum was observed (Table 2).

Some confusion over the identification of the Gymnodinium existed during the initial stages of the bloom, as this species exhibited some of the morphological characteristics of both Gymnodinium mikimotoi (i.e. straight apical groove, cell size and girdle displacement) and G. breve (i.e. pronounced hypotheca invagination); both 'large' and 'small' vegetative cells (see Silva \& Faust 1995) were observed in bloom populations (cell width 13 to $35 \mu \mathrm{m}$, cell length 17 to $37 \mu \mathrm{m})$. Although initially identified as G. cf. mikimotoi using light microscopy, the Gymnodinium species responsible for the Kuwait red tide was confirmed to be the type found in New Zealand that is being described as 'selliformis' which is similar to G. mikimotoi but morphologically and genetically distinct (Haywood et al. unpubl.). Identification was subsequently confirmed as this new Gymnodinium species by A. Haywood

Table 1. Chronology of Gymnodinium selliforme bloom and associated toxicity events in Kuwait in 1999

\begin{tabular}{|c|c|}
\hline Date & Observations \\
\hline $15 \mathrm{Sep}$ & $\begin{array}{l}\text { Fish kill }\left(\sim 15 \mathrm{t}, 1500 \mathrm{~km}^{2}\right) \text { along coast of } \\
\text { Khozestan Province, Iran }\end{array}$ \\
\hline $19 \mathrm{Sep}$ & $\begin{array}{l}\text { Fish kill ( } 25 \text { to } 30 \mathrm{t}) \text {, primarily mullet Liza } \\
\text { macrolepis in northern Kuwait Bay reported } \\
\text { by Kuwait EPA }\end{array}$ \\
\hline $20 \mathrm{Sep}$ & $\begin{array}{l}\text { Fish kill (L. macrolepis) in nearshore, northern } \\
\text { and southern Kuwait Bay. Kuwait EPA in- } \\
\text { formed Regional Organization for the Pro- } \\
\text { tection of the Marine Environment (ROPME) } \\
\text { of the event }\end{array}$ \\
\hline $21 \mathrm{Sep}$ & $\begin{array}{l}\text { Patches of discolored water observed south of } \\
\text { Kuwait Bay }\end{array}$ \\
\hline 28-29 Sep & $\begin{array}{l}\text { Discolored water observed off El-Bedee (Sal- } \\
\text { miya) Beach by overflight }\end{array}$ \\
\hline 1-2 Oct & $\begin{array}{l}\text { Fish kill ( } 80000 \text { fish) of sobaity seabream } \\
\text { Acanthopagrus cuvieri in mariculture farms } \\
\text { near Doha, Kuwait Bay }\end{array}$ \\
\hline 3 Oct & $\begin{array}{l}\text { Discolored water observed in Kuwait Bay, } \\
\text { continuation of fish death in mariculture farms }\end{array}$ \\
\hline $4 \mathrm{Oct}$ & $\begin{array}{l}\text { Dinoflagellate species causing discolored water } \\
\text { identified as Gymnodinium sp. by Kuwait } \\
\text { EPA, with cell concentrations }>6 \times 10^{6} \text { cells l}^{-1}\end{array}$ \\
\hline 12 Oct & $\begin{array}{l}\text { Patches of discolored water observed in north- } \\
\text { ern and southern Kuwait Bay with small } \\
(<100 \text { fish) daily fish kills in aquaculture en- } \\
\text { closures; Gymnodinium sp. dominated phyto- } \\
\text { plankton community in Kuwait Bay (cell con- } \\
\text { centrations }<0.5 \times 10^{6} \text { cells } 1^{-1} \text { ), with Meso- } \\
\text { dinium rubrum present }\end{array}$ \\
\hline 14 Oct & $\begin{array}{l}\text { Patches of discolored water observed. Sam- } \\
\text { ples contained a mixture of Gymnodinium sp. } \\
\text { and } M . \text { rubrum, with } M . \text { rubrum dominating } \\
\text { in discolored patches }\end{array}$ \\
\hline 15 Oct & $\begin{array}{l}\text { Patches of discolored water observed. Gym- } \\
\text { nodinium sp. dominated at aquaculture sites } \\
\text { with fresh fish kill }(<1000 \text { fish). At other sites, } \\
\text { M. rubrum dominated phytoplankton, with } \\
\text { Gymnodinium sp. present. Red water due to } \\
\text { M. rubrum }\end{array}$ \\
\hline 17 Oct & $\begin{array}{l}\text { Kuwait EPA advises against consumption of } \\
\text { both shellfish and fish guts and heads for a } \\
\text { minimum of } 30 \mathrm{~d}\end{array}$ \\
\hline
\end{tabular}




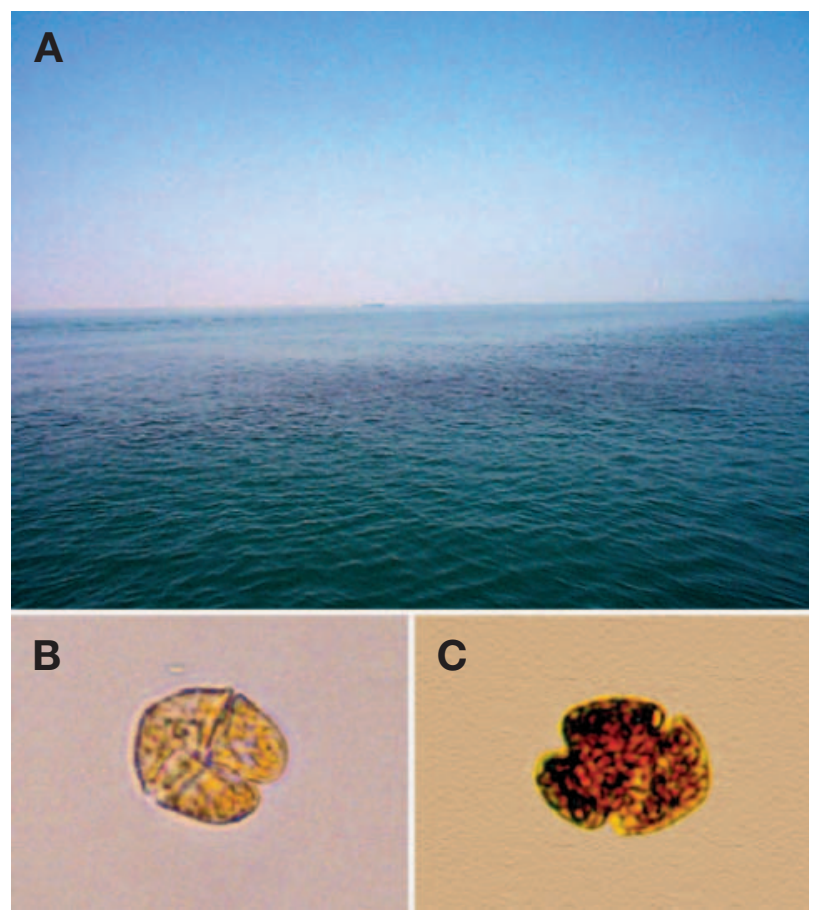

Fig. 2. (A) Red water in Kuwait Bay, October 14, 1999, (B) live Gymnodinium selliforme cells and (C) G. selliforme cells preserved with Lugol's solution blooms were previously unknown in this region. No adverse human effects were associated with this bloom. The closure of shellfish and selected finfish markets during the bloom resulted in significant economic losses to local markets (Elizabeth 1999).

Gymnodinium sp. concentrations in samples from October 4 exceeded $6 \times 10^{6}$ cells ${ }^{-1}$ in the area of fish kills. Analysis of phytoplankton community composition on October 14 at 4 established Kuwait EPA monitoring stations showed that Gymnodinium sp. dominated phytoplankton abundance at all stations except Stn 1, where high concentrations of the diatom Nitzschia sp. were present (Fig. 3A). A more comprehensive survey conducted the following day, which included principal outfall and aquaculture sites within Kuwait Bay, found high $\left(5.0 \times 10^{5}\right.$ cells $\left.1^{-1}\right)$ concentrations of Gymnodinium sp. at aquaculture pens associated with fresh fish kills. The ciliate Mesodinium rubrum was present at high concentrations during this survey (up to $5.7 \times 10^{5}$ cells $\mathrm{l}^{-1}$ ) at the primary industrial outfall site and within localized patches of reddish discolored water offshore of the beaches in southern Kuwait Bay (Fig. 3B).

No deviations from the normal seasonal range of physical environmental conditions was apparent in the Kuwait EPA monitoring data of Kuwait Bay prior to or
(Cawthron Institute, Nelson, New Zealand) and K. Steidinger (Florida Fish and Wildlife Conservation Commission, Florida Marine Research Institute, St. Petersburg, Florida) in December 1999, based on sample material provided by the Kuwait EPA. No G. breve was identified in any of the samples examined. Although other potentially toxic phytoplankton species were present within the area during the latter stages of the bloom (Table 2), none except Gymnodinium sp. were present at cell concentrations sufficient to cause harmful effects.

Limited aquaculture-related fish kills (<100 fish $\mathrm{d}^{-1}$ cage $^{-1}$ ) continued through the week of October 16. On October 17, the Kuwait EPA issued an alert advising against the consumption of shellfish and fish guts and heads for at least $30 \mathrm{~d}$. This advisory was finally lifted in March 2000. Local consumption of shellfish and finfish was greatly reduced during the initial stages of the bloom, as toxic algal
Table 2. List of phytoplankton species present in October 14 and 15 samples from Kuwait Bay during bloom event

\begin{tabular}{|lll|}
\hline Diatoms & Dinoflagellates & Others \\
\hline Asterionellopsis glacialis & Amphidinium carterae & Phaeocystis sp. \\
Bacteriastrum furcatum & Ceratium symmetriam & Mesodinium rubrum \\
Ceratiulina pelagica & Ceratium fusus & \\
Chaetoceros costatus & Dinophysis caudata & \\
Chaetoceros curvisetus & Dinophysis miles & \\
Chaetoceros debilis & Gymnodinium galantum & \\
Chaetoceros eibenii & Gymnodinium simplex & \\
Chaetoceros lorenzianus & Gymnodinium sp. & \\
Chaetoceros 'b' sp. & Gyrodinium fusiformis \\
Chaetoceros spp. & Gyrodinium spirale & \\
Coscinodiscus sp. & Gyrodinium spp. \\
Cylindrotheca clostridium & Polykrikos sp. \\
Eucampia zoodiacus & Prorocentrum concavum \\
Guidinardia flaccida & Prorocentrum emarginatum \\
Gyrosigma sp. & Prorocentrum lima & \\
Helicotheca tamesis & Prorocentrum micans & \\
Leptocylindrus sp. & Prorocentrum minimum & \\
Navicula spp. & Protoperidinium minutum & \\
Nitzschia spp. & Protoperidinium spp. \\
Paralia sulcata & Pyrophacus steinii & \\
Pleurosigma sp. & Scrippsiella troichiodea & \\
Pseudonitzschia sp. & \\
Rhizosolenia chunii & \\
Rhizosolenia setigera & \\
Skeletonema costatum & \\
Thalassionema nitzschoides & \\
Thalassiosira pseudonana & \\
apresent as both 'large' and 'small' vegetative cells & \\
& \\
\end{tabular}




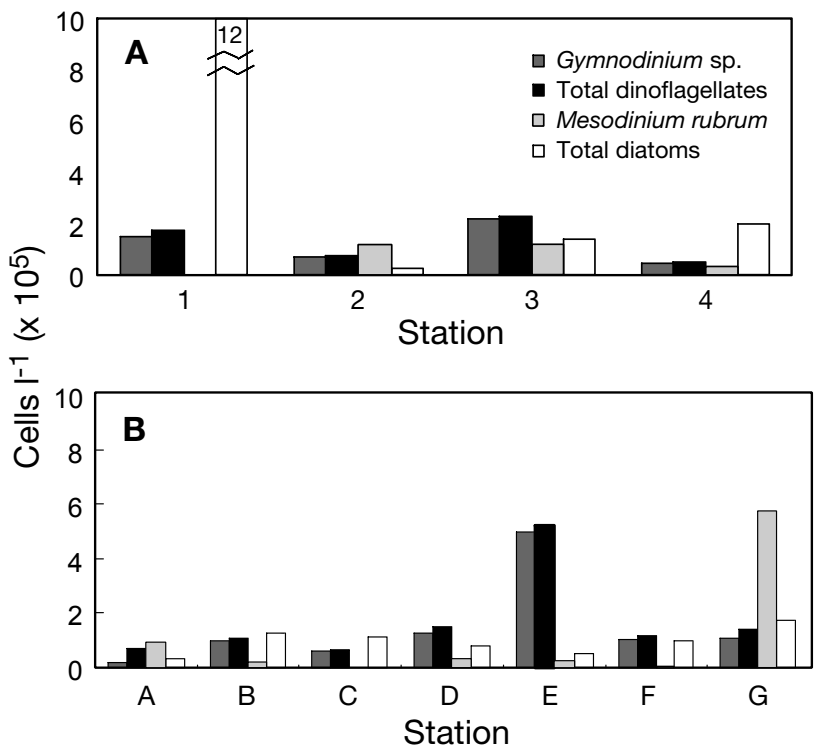

Fig. 3. Composition of the phytoplankton community for stations sampled on (A) October 14, 1999 and (B) October 15, 1999

during the bloom. Temperature ranged from to 26.9 to $28.6^{\circ} \mathrm{C}$, while salinity was consistently elevated at all stations sampled (from 41.32 to $42.59 \%$ ). Dissolved oxygen concentrations ranged from 3.07 to $5.05 \mathrm{mg} \mathrm{l}^{-1}$ and displayed no relationship with dinoflagellate concentration. Secchi depths were reduced compared with pre-bloom data (Kuwait EPA 1999), probably due to high cell biomass. Concentrations of chlorophyll $a$ ranged from $1.4 \mathrm{\mu g} \mathrm{l}^{-1}$ in the non-bloom sites of the mid-Bay to $14.3 \mathrm{\mu g} \mathrm{l}^{-1}$ in the bloom patches (data not shown). Preceding the bloom, low winds and a calm, stable water-column structure persisted throughout Kuwait Bay.

From examination of the mean concentrations of inorganic nutrients in the months preceding the 1999 Kuwait red tide, it is apparent that just prior to the bloom concentrations of nitrogen increased substantially (Fig. 4A). Ambient nitrogen concentrations during the months of July and August averaged $<5 \mu \mathrm{M}$, while concentrations in September were nearly double those in previous months. In early October, coincident with the establishment of the bloom, mean concentrations rapidly escalated, such that they were nearly 20-fold those observed in earlier months. A similar comparison for $\mathrm{PO}_{4}{ }^{3-}$ concentrations also revealed an increase from the pre-bloom to early bloom phases; however, the increases were significantly less than those of nitrogen (Fig. 4B). Average concentrations of $\mathrm{Si}(\mathrm{OH})_{4}$ for the months preceding the bloom varied between 15.8 and $35.6 \mu \mathrm{M}$, with higher concentrations occurring in the weeks just before the bloom (data not shown). During the months of July through August 1999, based on the available monitoring data, the molar ratio of nitrogen:phosphorus was less than that required to balance phytoplankton growth, suggesting limitation by nitrogen. During the early phases of the red tide, with elevated nitrogen, the balance of nutrients was altered to indicate an excess of nitrogen. Consequently, the mean nitrogen:phosphorus ratio of the dissolved nutrients increased nearly 5-fold from August to October (Fig. 4C). Similarly, the mean nitrogen:silicon ratio increased from 0.20 in July to 1.0 in October (Fig. 4D).

During the period October 14 and 15, inorganic nutrient concentrations were not elevated, and concentrations were more similar to those observed in July and August (Fig. 5). This may reflect uptake of these nutrients by the plankton. Data on organic nutrients are not available prior to the sampling of October 14 and 15 , but the concentrations during this period suggest a substantial contribution of organic nutrients to the overall nutrient pool (Table 3). On average, DON represented $84 \%$ and DOP $64 \%$ of the total dissolved nitrogen and phosphorus. Urea concentrations ranged from 0.12 to $-1.05 \mu \mathrm{g}$ at. $\mathrm{N}^{-1}$, which represented on average $\leq 2 \%$ of the total DON. At the current time, it is not known whether these values are typical for Kuwait Bay.
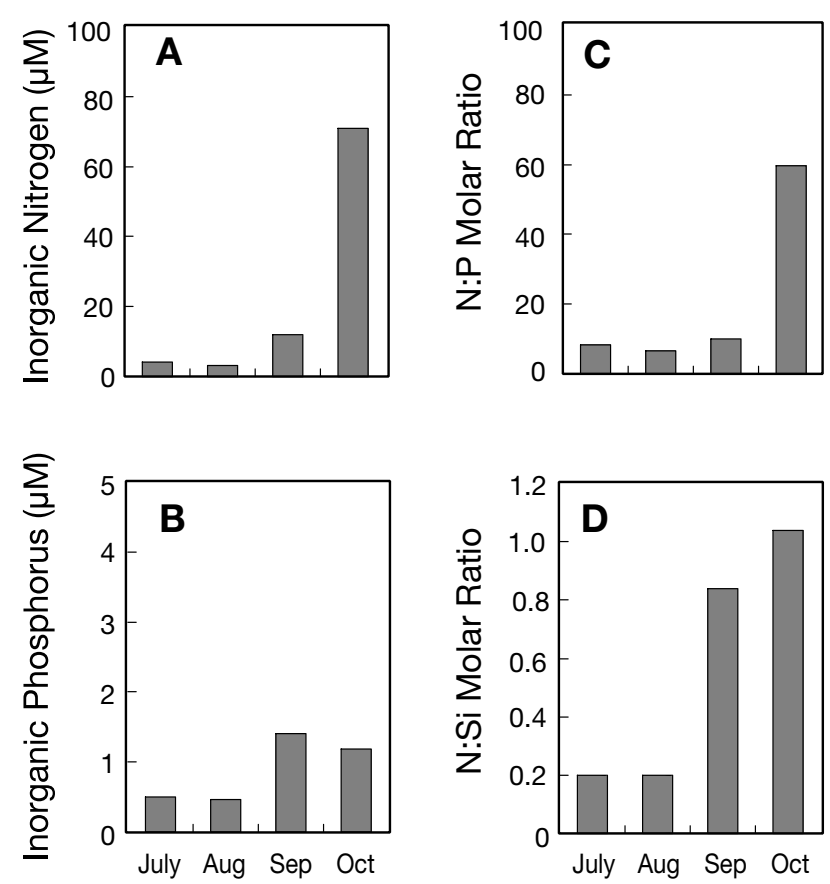

Fig. 4. Mean concentrations of inorganic nitrogen, inorganic phosphorus, molar N:P ratio and molar N:Si ratio in months leading up to the Gymnodinium sp, bloom in Kuwait Bay. Data are from long-term monitoring sites from the Kuwait EPA 


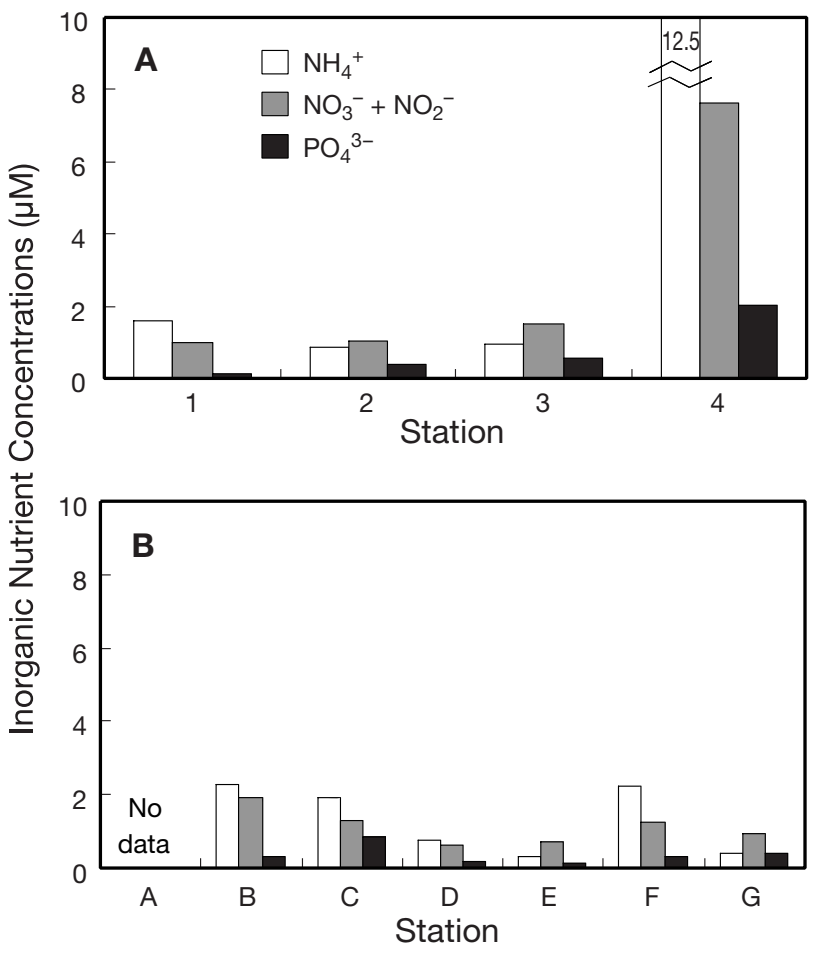

Fig. 5. Inorganic nutrient concentrations for stations sampled on (A) October 14, 1999 and (B) October 15, 1999

\section{DISCUSSION}

The October 1999 bloom of Gymnodinium sp. in Kuwait Bay is thought to be the first such event leading to fish kills in the Arabian Gulf. Two different organisms were involved in the 'red water' event which was coincident with fish kills in Kuwait Bay-the toxic dinoflagellate Gymnodinium sp. and the non-toxic ciliate Mesodinium rubrum. The sequence of red water observations and fish kills suggest that the early bloom water discoloration was due to extremely high dinoflagellate concentrations which resulted in fish kills early in the event. Red water observed in the later stages of the bloom after the majority of fish kills occurred (after October 12) could be attributed almost entirely to $M$. rubrum by direct cell counts. Blooms of $M$. rubrum have previously been found to discolor water, possibly

Table 3. Mean $( \pm \mathrm{SD})$ concentrations $(\mu \mathrm{M})$ of DOC, DON and DOP in samples collected on dates indicated. Also shown is mean percent contribution of urea to the DON pool

\begin{tabular}{|lcccc|}
\hline $\begin{array}{l}\text { Date } \\
(1999)\end{array}$ & DOC & DOP & DON & $\begin{array}{l}\% \text { DON } \\
\text { as urea }\end{array}$ \\
\hline Oct 14 & $214.8(11.9)$ & $0.25(0.13)$ & $20.9(4.4)$ & $2.0(1.5)$ \\
Oct 15 & $203.5(28.4)$ & $0.32(0.27)$ & $16.2(5.9)$ & $1.6(1.0)$ \\
\hline
\end{tabular}

due to the release of extracellular products (Sellner 1981, Crawford 1989). Red water was previously observed during a bloom of the non-toxic dinoflagellate Gyrodinium instriatum in Kuwait Bay (Subba-Rao et al. 1999); thus the presence of red water in Kuwait Bay is not always indicative of potential fish toxicity.

Red tides and the presence of potentially toxic phytoplankton species in the northwestern Arabian Sea have been previously documented (Subba Rao \& AlYamani 1998, Subba Rao et al. 1999). Subba Rao et al. (1999) described a bloom of the dinoflagellate Gyrodinium instriatum in Kuwait Bay in 1997 that was characterized by high biomass (>200 $\mu \mathrm{g}$ chlorophyll a $\mathrm{l}^{-1}$ ) and primary productivity (>500 $\mathrm{gg} \mathrm{C}^{-1} \mathrm{~h}^{-1}$ ), but was not toxic to fish or shellfish. Blooms of the photosynthetic ciliate Mesodinium rubrum were also reported for Kuwaiti Bay in October of 1995, with concentrations up to $160 \mu \mathrm{g}$ chlorophyll a $\mathrm{l}^{-1}$ and cell concentrations of $1.08 \times 10^{6}$ cells $^{-1}$ (Al-Yamani et al. 1997). Other potentially toxic phytoplankton species (e.g. Pyrodinium bahamense, Lingulodinium polyedra, Phaeocystis sp.) have been reported within the northern Arabian Gulf (Dorgham \& Moftah 1989, Al-Yamani et al. 1997, Subba-Rao \& Al-Yamani 1998).

Taxonomy of the unarmoured dinoflagellate genus Gymnodinium is currently under revision based on electron microscopy and immunological and molecular techniques (Takayama et al. 1998, Hansen et al. 2000, Haywood et al. 2000). This genus is extremely pleomorphic, and significant changes in morphology occur upon preservation due to osmotic sensitivity, often making identification difficult (Steidinger \& Tangen 1996, Steidinger et al. 1996, Hansen et al. 2000). Diagnostic characteristics of species are poorly defined and morphological differences between species are often subtle, requiring observation of a large number of cells or electron microscopy. Gymnodinium sp., initially described from New Zealand waters (Haywood et al. unpubl.), has also been found in bloom concentrations in the northeastern Gulf of Mexico (K. Steidinger pers. comm.). This species contains the toxin gymnodimine, which is toxic to both mice and fish (Seki et al. 1996) and can produce false positive neurotoxic shellfish poisoning (NSP) results (MacKenzie et al. 1995, 1996). Given the confusion in identification of toxic Gymnodinium species (e.g. Gyrodinium aureolum, Gymnodinium mikimotoi, G. cf. mikimotoi) and the description of new, toxic Gymnodinium species (Haywood et al. unpubl.), it is likely that blooms of Gymnodinium sp. are not restricted to Kuwait Bay, Gulf of Mexico and New Zealand coastal waters and have been misidentified in other areas.

Two alternative hypotheses can explain the observed chronology of the bloom and associated fish kills in Kuwait Bay. Climatic and environmental conditions 
may have been such that the bloom developed simultaneously in Iranian and Kuwait waters. Circulation in the northwestern Gulf is an anti-clockwise rotation, however (Hunter 1986, Sheppard et al. 1992, Reynolds 1993). Combined with a report of significant fish kills in Iranian coastal waters almost 2 wk prior to the kills in Kuwait Bay, this suggests that the dinoflagellate may have been present in Iranian waters prior to its appearance in Kuwait Bay, although there are no data currently available to support or refute this. Given current speeds of up to $18.9 \mathrm{~cm} \mathrm{~s}^{-1}$ (Reynolds 1993), transport of bloom populations from Iran to Kuwait coastal waters could have occurred within $2 \mathrm{wk}$. We also cannot discount the possibility that the Iranian fish kill was completely unrelated to the Kuwaiti event and was due to other causes.

Nutrient measurements made prior to and during the bloom suggest that elevated nutrients, particularly inorganic nitrogen, may have played a role in initiation and/or maintenance of this bloom. Dramatic elevation in inorganic nitrogen and phosphorus levels (up to 20-fold for nitrogen) occurred from late August to early October. The direct source of this nutrient input at this time, however, is unknown. Depletion in silicate relative to nitrogen and phosphorus has also been suggested to favor the outbreak of some harmful bloom species (e.g. Smayda 1989, 1990); however, this was not the case here. In fact, during the bloom, the N:Si ratio was favorable for diatom production.

Of particular note is the high proportion of DON and DOP in Kuwait Bay in October 1999. While data on organic nutrients are not available prior to the October 14 and 15, 1999, sampling, the percent contribution of organic nitrogen and phosphorus to the total dissolved nutrient pool during the bloom exceeded $60 \%$. Recent studies in enriched coastal areas have shown that, while productivity may increase quantitatively with overall nitrogen availability, the DON component may contribute disproportionately to the alteration of phytoplankton succession, leading to the development of harmful algal blooms (Pearl 1988, Berg et al. 1997, LaRoche et al. 1997, Lomas et al. 2001). There are several reasons for this. Many harmful bloom species are mixotrophic or heterotrophic and derive some or all of their energy and nutrition from the uptake of organic molecules or from direct feeding (e.g. Burkholder \& Glasgow 1997, Stoecker et al. 1997). It is also possible that nutrient-rich, particularly organic-nutrient-rich, conditions may stimulate other organism(s) that may, in turn, have a stimulatory effect on the harmful bloom species. At this time, there are no available data on the extent to which Gymnodinium sp. is or is not mixotrophic.

Two factors previously found to be associated with outbreaks of dinoflagellate blooms are elevated ratios of DOC:DON and elevated concentrations of urea (Glibert \& Terlizzi 1999, Glibert, Magnien, Lomas, Alexander, Fan, Haramoto, Trice \& Kana unpubl. data). When Gymnodinium sp. dominated the phytoplankton community in Kuwait Bay, the ratio of DOC:DON was approximately twice that of the period when Mesodinium rubrum dominated, or when a mixed assemblage was encountered (data not shown). High concentrations of urea have been found to be associated with dinoflagellate blooms in enclosed aquaculture systems (Glibert \& Terlizzi 1999). In the Kuwait aquaculture stations, urea was not elevated significantly over other stations, but, overall, the concentrations of urea were relatively high (on average $>0.6 \mu \mathrm{g}$ at. $\mathrm{N}^{-1}$ ). The potential role of aquaculture in the dynamics of this bloom must be considered, however, as aquaculture ponds and cage culture systems represent an additional source of nutrients to coastal waters. Conditions in and around pens are generally nutrient-enriched, particularly in nitrogen, which can be derived from feed and fertilizer as well as intensified biological transformations (Cho et al. 1996, Burford 1997, Burford \& Glibert 1999). The aquaculture industry in Kuwait Bay is relatively recent, with production levels of $500 \mathrm{t} \mathrm{yr}^{-1}$ and $600 \mathrm{t}$ of fish in stock (Kuwait Environmental Public Authority 1999). Finfish are a staple of the Kuwaiti diet, and high demands from local markets as well as overexploitation of local fisheries (Al-Mubarak et al. 1999, ROPME 1999) suggest that intensification of aquaculture industry in the region will continue.

Concentrations of both inorganic and organic nutrients measured during the bloom suggest that Kuwait Bay is subject to elevated nutrient loadings from a variety of sources. Industrial and sewage inputs contribute significant inorganic nutrient inputs to the northern Arabian Gulf (ROPME 1999), but their contribution to organic nutrient loading in unknown. The magnitude of nutrient inputs from the relatively recent introduction of aquaculture to the region is also unknown. Iraq has destroyed much of the wetlands area in the region to the northeast and upcurrent of Kuwait at the conjunction of the Tigres, Euphrates and Karoon Rivers and constructed a 'third river' drainage channel which now inputs an additional unknown quantity of pollutants into the northern Arabian Sea (ROPME 1999). Nutrients derived from any one or all of these sources may have provided optimal conditions for bloom initiation and development. The impacts of chronic oil pollution in the area must also be considered, as it has been shown from mesocosm experiments that chronic oil-enrichment enhances phytoplankton biomass and primary production via the reduction of pelagic and benthic grazers (Elmgren et al. 1978). Alterations in trophic dynamics within the region associated with 
both chronic and Gulf War related oil pollution may also have contributed to environmental conditions optimal for Gymnodinium sp. growth. This toxic algal bloom event highlights the need for monitoring and research programs in the Arabian Sea and Kuwait Bay that focus on nutrients and eutrophication in addition to oil-related pollution issues.

Note added in proof: Gymnodinium breve, G. brevisulcatum and G. mikimotoi were recently transferred to the new genus Karenia (Daugbjerg et al. 2000). The Gymnodium sp. that bloomed in Kuwait Bay belongs to this new genus and will be included in it when named (Haywood et al. unpubl.).

Acknowledgements. This work was supported by a contract from the Kuwait Environment Public Authority (EPA) and by grants no. R826792-01-0 (Florida) and NA866OP0493 (Maryland) from the US ECOHAB Program. The expert assistance of the staff of the Kuwait EPA, including the Captain and crew of the research vessel, is especially appreciated. Dr F. AlYamani (Kuwait Institute of Scientific Research), Professor R. Al-Hassan (Kuwait University) and Dr A. R. Moftah (Qatar University) provided helpful discussions regarding the bloom. The assistance of M. Trice, J. Alexander, E. Haramoto, C. Fan and the Horn Point Analytical Services Laboratory is also appreciated. We are also grateful to Dr Y. Shimizu, Department of Pharmacology and Environmental Health, University of Rhode Island, for provision of toxin expertise and advice. Identification of the dinoflagellate would not have been possible without the assistance of A. Haywood of the Cawthorne Institute, Nelson, New Zealand, and K. Steidinger of the Florida Fish and Wildlife Conservation Commission, Florida Marine Research Institute, St. Petersburg, Florida, who generously provided time, taxonomic advice and access to unpublished data. We also thank T. Kana for his advice and assistance. This is contribution no. 3390 from the University of Maryland Center for Environmental Science.

\section{LITERATURE CITED}

Abou-Seida MM, Al-Sarawi MA (1990) Utilization and management of coastal areas in Kuwait. Coast Mgmt 18: 385-401

Al-Abaychi J, Ghani A (1986) Study of seasonal variations of nutrients and other parameters with direct effect on the waters of Khor Az-Zubair and Shatt Al-Basra. In: The First Symposium on marine environment for Khor Az-Zubair, Al-Basra

Al-Mubarak KA, Siddiqui MS, Jamal AH, Mittu KT (1999) Fin-fish fisheries' potential in the territorial waters of Kuwait. Estuar Coast Shelf Sci 49(Suppl A):83-86

Al-Yamani F, Bishop J, Ismaeil W, Al-Rifaie K, Al-Yaquoit A, Al-Salid T, Kwarteng A, Al-Ghadban A, Al-Omran L, Sheppard C (1997) Assessment of the effects of the Shatt Al-Arab's altered discharge regimes on the ecology of the northern Arabian Gulf. Kuwait Institute for Scientific Research, Safat (Final Rep-FM006K)

Anderlini VC, Jacob PG, Lee JW (1982) Atlas of physical and chemical characteristics of Kuwait Bay. Kuwait Institute for Scientific Research, Safat

Berg GM, Glibert PM, Lomas MW, Burford MA (1997) Organic nitrogen uptake and growth by the chrysophyte Aureococcus anophagefferens during a brown tide event. Mar Biol 129:377-387
Bronk DA, Lomas MW, Glibert PM, Schukert KJ, Sanderson MP (2000) Total dissolved nitrogen analysis: comparisons between persulfate, UV, and high temperature oxidation methods. Mar Chem 69:163-178

Burford MA (1997) Phytoplankton dynamics in shrimp ponds. Aquacult Res 28:351-360

Burford MA, Glibert PM (1999) Short-term nitrogen uptake and regeneration in early and late growth phase shrimp ponds. Aquac Res 30:215-227

Burkholder JM, Glasgow HB Jr (1997) The ichthyotoxic dinoflagellate Pfiesteria piscicida: behavior, impacts, and environmental controls. Limnol Oceanogr 42:1052-1075

Carpenter KE, Harrison PL, Hodgson G, Alsaffar AH, Alhazeen SH (1997) The corals and coral reef fishes of Kuwait. Fahad Al-Marzouk Printing \& Publishing Establishment, Safat, Kuwait

Cava FM, Robinson JH, Earle SA (1993) Should the Arabian (Persian) Gulf become a marine sanctuary? Oceanus 36: 53-59

Cho BC, Park MG, Shim JH, Azam F (1996) Significance of bacteria in urea dynamics in coastal surface waters. Mar Ecol Prog Ser 142:19-26

Crawford DW (1989) Mesodinium rubrum: the phytoplankton that wasn't. Mar Ecol Prog Ser 58:161-174

Daugbjerg N, Hansen G, Larson J, Moestrop Ø (2000) Phylogeny of some of the major genera of dinoflagellates based on ultrastructure and partial LSU rDNA sequence data, including the erection of three new genera of unarmoured dinoflagellates. Phycologia 39:302-317

Dorgham MM, Moftah A (1989) Environmental conditions and phytoplankton distribution in the Arabian Gulf and Gulf of Oman, September 1986. J Mar Biol Assoc India 31: $36-53$

Elizabeth H (1999) Red tide...fish safe to eat. Kuwait Times, October 16, p 1

Elmgren R, Vargo GA, Grassle JF, Grassle JP, Heinle DR, Langlois G, Vargo SL (1978) Trophic interactions in experimental marine ecosystems perturbed by oil. In: Geisy JP (ed) Microcosms in ecological research. DOE Symposium Series, Augusta, Georgia, p 850-868

Glibert PM, Terlizzi DE (1999) Co-occurrence of elevated urea levels and dinoflagellate blooms in temperate estuarine aquaculture ponds. Appl Environ Microbiol 65: $5594-5596$

Golob R, Bruss E (1984) Statistical analysis of oil pollution in the Kuwait Action Plan Region and the implications of selected world-wide oil spills to the region. In: Combating oil pollution in the Kuwait Action Plan Region. United Nations Environmental Program Regional Seas reports and studies, No. 44, Geneva, p 7-34

Hadi RAM, Al-Mousawi AH, Al-Zubaidy AJM (1989) A study on the primary productivity in the Shatt Al-Arab estuary at Basrah, Iraq. J Biol Sci Res 20:593-606

Hallegraeff GM (1995) Harmful Algal Blooms: a global overview. In: Hallegraeff GM, Anderson DM, Cembella AD (eds) Manual on harmful marine microalgae. UNESCO Paris, p 1-22 (IOC Manuals and Guides No. 33)

Hansen G, Daugbjerg N, Henriksen P (2000) Comparative study of Gymnodinium mikimotoi and Gymnodinium aureolum, comb. nov. (=Gyrodinium aureolum) based on morphology, pigment composition, and molecular data. J Phycol 36:394-410

Hasle GR (1978) 7.3 Using the inverted microscope. In: Sournia A (ed) Phytoplankton manual. Monogr Oceanogr Methodol 6:191-196

Hunter JR (1986) The physical oceanography of the Arabian Gulf: a review and theoretical interpretation of previous 
observations. In: Halwagy R, Cleyton D, Behbehani M (eds) First Conference on Environment and Pollution. Kuwait University, Kuwait City, p 1-25

Jacob PG, Al-Muzaini A (1990) Marine plants of the Arabian Gulf: a literature review. Kuwait Institute for Scientific Research, Safat, Kuwait (KISR Tech Rep No. 3426)

Kuwait Environmental Public Authority (KEPA) (1999) Summary report on fish kill, September-October 1999. KEPA, Safat

LaRoche JR, Nuzzi R, Waters R, Wyman K, Falkowski PG, Wallace DWR (1997) Brown tide blooms in Long Island's coastal waters linked to variability in groundwater flow. Glob Change Biol 3:397-410

Lehr WJ (1984) A brief survey of oceanographic modeling and oil spill studies in the KAP region. In: El-Sabh MI (ed) Oceanographic Modeling of the Kuwait Action Plan (KAP) Region. UNESCO, Paris, p 4-11 (Rep Mar Sci No. 28)

Literathy P (1993) Considerations for the assessment of environmental consequences of the 1991 Gulf War. Mar Pollut Bull 27:349-356

Lomas MW, Glibert PM, Clougherty DA, Huber DE, Jones J, Alexander J, Haramoto E (2001) Elevated organic nutrient ratios associated with brown tide blooms of Aureococcus anophagefferens (Pelagophyceae). J Plankton Res (in press)

MacKenzie L, Rhodes L, Till D, Chang FH, Kaspar H, Haywood A, Kapa J, Walker B (1995) A Gymnodinium sp. bloom and the contamination of shellfish with lipid soluble toxins in New Zealand, Jan-April 1993. In: Lassus P, Arzul G, Erard-LeDenn E, Gentien P, Marcaillou-Le Baut C (eds) Harmful marine algal blooms. Lavoisier, Paris, p 795-800

MacKenzie L, Haywood A, Adamson J, Truman P, Till D, Seki T, Satake M, Yasumoto T (1996) Gymnodimine contamination of shellfish in New Zealand. In: Yasumoto $\mathrm{T}$, Oshima Y, Fukuyo Y (eds) Harmful and toxic algal blooms. Intergovernmental Oceanographic Commission of UNESCO, Paris, p 97-100

Parsons TR, Maita Y, Lalli CM (1984) A manual of chemical and biological methods for seawater analysis. Pergamon Press, Oxford

Pearl HW (1988) Nuisance phytoplankton blooms in coastal, estuarine, and inland waters. Limnol Oceanogr 33: 823-847

Readman JW, Fowler SW, Villeneuve JP, Cattinin C, Oregioni B, Mee ML (1992) Oil and combustion-product contamination of the Gulf marine environment following the war. Nature (Lond) 358:662-665

Reynolds M (1993) Physical oceanography of the Gulf, Strait of Hormuz, and the Gulf of Oman: results from the Mt Mitchell expedition. Mar Pollut Bull 27:35-59

ROPME (Regional Organization for the Protection of the Marine Environment) (1999) Regional Report of the State of the Marine Environment, Regional Organization for the Protection of the Marine Environment, State of Kuwait, March 1999

Saad MAH (1976) Observations on the problems of pollution in Shatt-Al-Arab, Iraq. Rev Int Oceanogr Med 43:3-11

Editorial responsibility: Otto Kinne (Editor), Oldendorf/Luhe, Germany
Seki T, Satake M, MacKenzie L, Kaspar HF, Yasumoto T (1996) Gymnodinimine, a novel toxic imine isolated from the Foveaux Strait oysters and a Gymnodinium sp. In: Yasumoto T, Oshima Y, Fukuyo Y (eds) Harmful and toxic algal blooms. Intergovernmental Oceanographic Commission of UNESCO, Paris, p 495-498

Sellner KG (1981) Primary productivity and the flux of dissolved organic matter in several marine environments. Mar Biol 65:101-112

Sheppard CRC (1993) Physical environment of the Gulf relevant to marine pollution: an overview. Mar Pollut Bull 27: 3-8

Sheppard CRC, Price ARG, Roberts CM (1992) Marine ecology of the Arabian region: patterns and processes in extreme tropical environments. Academic Press, London

Silva ES, Faust MA (1995) Small cells in the life history of dinoflagellates (Dinophyceae): a review. Phycologia 34: $396-408$

Smayda TJ (1989) Primary production and the global epidemic of phytoplankton blooms in the sea: a linkage? Coast Estuar Stud 35:449-483

Smayda TJ (1990) Novel and nuisance phytoplankton blooms in the sea: evidence for a global epidemic. In: Granéli E et al. (eds) Toxic marine phytoplankton. Elsevier, Amsterdam, p 29-40

Steidinger KA, Tangen K (1996) Dinoflagellates. In: Tomas CR (ed) Identifying marine diatoms and dinoflagellates. Academic Press, New York, p 387-584

Steidinger KA, Landsberg JH, Truby EW, Blakesley BA (1996) The use of scanning electron microscopy in identifying small 'gymnodinioid' dinoflagellates. Nova Hedwigia 112: $415-422$

Stoecker DK, Li A, Coats W, Gustafson DE, Nannen MK (1997) Mixotrophy in the dinoflagellate Prorocentrum minimum. Mar Ecol Prog Ser 152:1-12

Subba-Rao DV, Al-Yamani F (1998) Phytoplankton ecology in the water between Shatt Al-Arab and the Straits of Hormuz, Arabian Gulf: a review. Plankton Biol Ecol 45: 101-116

Subba-Rao DV, Al-Yamani F, Lennox A, Pan Y, As-Said TFO (1999) Biomass and production characteristics of the first red tide noticed in Kuwait Bay, Arabian Gulf. J Plankton Res 21:805-810

Takayama H, Matsuoka K, Fukuyo Y (1998) A taxonomic study on Gyrodinium aureolum Hulburt (Dinophyceae) from the morphological viewpoint based on material collected in Japanese coastal waters. Bull Plankton Soc Jpn 45:9-19

Throndsen J (1995) Estimating cell numbers. In: Hallegraeff GM, Anderson DM, Cembella AD (eds) Manual on harmful marine microalgae. UNESCO, Paris, p 63-80 (IOC Manuals and Guides No. 33)

Valderrama JC (1981) The simultaneous analysis of total nitrogen and total phosphorus in natural waters. Mar Chem 10:109-122

Submitted: May 22, 2000; Accepted: November 22, 2000

Proofs received from author(s): March 20, 2001 